\title{
EKSISTENSI GURU MBELIN DALAM PENGOBATAN TRADISIONAL KARO DI DESA KIDUPEN KECAMATAN JUHAR KABUPATEN KARO (1970-1990)
}

\author{
Oleh: \\ Rosmaida Sinaga \\ Marsella Br Sembiring
}

\begin{abstract}
ABSTRAK
Penelitian ini bertujuan untuk mengetahui : sejarah guru Mbelin dalam pengobatan tradisional Karo di desa Kidupen, faktor-faktor yang melatarbelakangi guru Mbelin banyak dikunjungi pada tahun 1970-1990 di desa Kidupen, faktor-faktor yang mendorong bertahannya guru Mbelin dalam pengobatan tradisional Karo di desa Kidupen dan peramuan bahan rempah-rempah oleh guru Mbelin dalam pengobatan tradisional Karo di desa Kidupen. Penelitian ini menggunakan metode sejarah dalam kajian Eksistensi Guru Mbelin Dalam Pengobatan Tradisional Karo Di Desa Kidupen yakni observasi atau pengamatan terhadap keadaan-keadaan, perkembangan serta pengalaman di masa lalu mengenai sejarah keberadaan guru Mbelin dalam pengobatan tradisional Karo di desa Kidupen dan meneliti dengan bukti-bukti yang valid dari sumber-sumber sejarah, menginterpretasi dengan sumber-sumber keterangan yang di peroleh, dan membandingkannya dengan keadaan pada masa sekarang. Hasil penelitian menunjukkan keberadaan dan perkembangan guru Mbelin dalam pengobatan tradisional Karo pada tahun 1970-1990 berkembang pesat hingga keluar daerah Karo. Perkembangan ini dalam hal pengobatan berbagai jenis penyakit baik personalistik (roh-roh halus) dan naturalistik (ketidakseimbangan unsur-unsur dalam tubuh) dengan menggunakan ramuan rempah-rempah alami dari alam dan tabas-tabas (mantramantra) yang dipercaya memiliki khasiat dalam menyembuhkan berbagai jenis penyakit. Proses pengobatan yang dilakukan guru Mbelin yakni mendiagnosis terlebih dahulu penyakit yang di derita pasien, kemudian menentukan metode pengobatan yang digunakan seperti menggunakan ramuan, metode tindakan dan gabungan antara keduanya, setelah itu dipakai oleh pasien dengan beberapa cara seperti diminum, dioleskan ketubuh dan lain-lainnya. Alasan masyarakat memilih pengobatan tradisional oleh guru Mbelin yakni kepercayaan masyarakat masih dinamisme dan animisme (serba roh), pengaruh tradisi yang sangat dipegang teguh masyarakat, biaya murah serta tempat yang mudah dijangkau dan rempah-rempah yang digunakan yaitu rempah-rempah dari alam sehingga mudah untuk di peroleh. Sehingga dapat disimpulkan eksistensi guru Mbelin dalam pengobatan tradisional Karo di desa Kidupen pada tahun 1970-1990 yakni sangat eksis.
\end{abstract}

Kata Kunci : Guru Mbelin, Pengobatan tradisional, Karo 


\section{PENDAHULUAN}

Masyarakat Indonesia merupakan masyarakat majemuk, karena memiliki beraneka ragam suku bangsa dengan budaya yang berbeda-beda. Keanekaragaman tersebut telah melahirkan berbagai tradisi yang diturunkan dari generasi ke generasi yang memperkaya budaya Indonesia. Salah satu unsur kebudayaan daerah yang bersifat universal ialah unsur kebudayaan yang berkenaan dengan pengobatan tradisional.

Tradisi suku Karo tidak membedakan antara agama, kekuatan sihir, adat istiadat, budaya, kepercayaan, perayaan atau upacara-upacara, pengobatan penyakit, semua hal itu saling berhubungan antara satu dengan lainnya dengan perbegu. Istilah perbegu berkaitan dengan keberadaan roh-roh leluhur, berbagai ritual dan upacara yang berhubungan dengan begu dilakukan melalui perantara seorang guru.

Orang karo sejak zaman prahistoris percaya adanya "Dibata" (Tuhan, Dewata) yakni "Dibata Kaci-Kaci", yang menciptakan segala hal yang ada di bumi dan jagad raya. Dalam masyarakat Karo secara tradisional terdapat religi yang telah memadukan ke serba-roh-an dengan sistem kedewataan secara serasi, saling melengkapi tanpa ada yang mau menang atau kalah (Ginting, 1990:1).

Kepercayaan orang Karo mempengaruhi cara berpikir masyarakat secara mistis dan kehidupan dikelilingi oleh kekuatan-kekuatan gaib, serta memakai mitos-mitos untuk memahami, mengatur, mengarahkan hidup dan lingkungannya, sehingga dalam pelaksanaan selalu terpusat pada guru. Guru bagi orang Karo untuk menyebut seseorang yang berperan sebagai Tabib, namun ada juga yang menyamakannya dengan Dukun. Di dalam pikiran mereka peranan guru sangat penting, karena bisa membantu mengatasi penyakit, membaca hari dan bulan baik, memanggil roh dan arwah, memberi semangat, memperoleh hajat dan lain-lain sebagainya.

Seorang guru dianggap memiliki pengetahuan yang dalam dan luas tentang berbagai hal yang berhubungan dengan kehidupan dan segala kejadian-kejadian yang terjadi dalam kehidupan manusia. Adapun berbagai pengetahuan yang dimiliki guru tersebut yakni praktek dan kepercayaan tradisional (meramal), memimpin upacara 
tradisional Karo yang berhubungan dengan roh, perawatan dan pengobatan berbagai penyakit dan lain-lain. Hal ini membuktikan tentang keberadaan seorang guru sebagai tempat kumpulan berbagai informasi ditengah masyarakat Karo.

Pengobatan penyakit secara tradisional, masyarakat Karo memiliki filosofi pengobatan yakni “lit bisa lit tawar" yang berarti setiap ada penyakit pasti ada obatnya. Masyarakat Karo sejak dulu telah mengenal obat-obat tradisional yang beragam seperti pengobatan patah tulang, oukup, kesaya, dampel-dampel, surung-surung, minyak urut dan lain-lainnya. Pengobatan tersebut melalui perantara dari seorang guru baik dalam meramu maupun memberi mantra-mantra yang dapat membantu menyembuhkan penyakit, hal ini menunjukkan bahwa masyarakat Karo mengenal beberapa jenis penyakit dan cara-cara mengobatinya.

Desa Kidupen merupakan salah satu daerah yang terkenal dengan keberadaan seorang guru, sehingga daerah tersebut sering dijuluki sebagai rumah para guru oleh masyarakat Karo. Berbagai jenis Guru serta keahlian masing-masing dalam berbagai bidang berada di desa Kidupen seperti guru Mbelin, guru Sibaso, guru Penawar, guru Siniktikwari, guru Perjinujung dan lain-lainnya. Salah satu guru yang paling berpengaruh di Desa Kidupen yaitu guru Mbelin yang disebut juga dengan guru Besar yang terkenal memiliki berbagai kemampuan baik dalam berhubungan dengan makhluk halus maupun dalam mengobati penyakit

Pada tahun (1970-1990) keberadaan guru Mbelin di Desa Kidupen sangat terkenal hingga keluar dari desa tersebut, hal ini dapat dilihat dari guru yang sering menunjukkan keilmuan dan kekuatannya kepada masyarakat agar diakui bahwa dia Guru yang hebat seperti kemampuan menyantet (Pengkayah), membuat pelaris dalam dagangan, memimpin upacara-upacara tradisional, menyembuhkan berbagai penyakit baik dengan menggunakan mantra-mantra (tabas-tabas) maupun dengan rempahrempah tradisional dan menyakiti orang lain.

Pada tahun (1990) keberadaan guru Mbelin mulai menurun, disebabkan oleh kedatangan agama Kristen, pengaruh dari perkembangan zaman yang modern dan pendidikan. Keberadaan seorang guru di Kabupaten Karo memang semakin berkurang 
pemakaiannya khususnya di desa Kidupen baik dalam berbagai kegiatan upacara yang bersifat ritual maupun dalam pengobatan tradisional . Jika tidak dilestarikan baik oleh masyarakat, pengobatan tradisional Karo dapat hilang. Sungguh menggembirakan bahwa dalam percampuran agama, pemikiran, kepercayaan dan kebudayaan pada masyarakat Karo berjalan dengan mulus dan damai, tidak menimbulkan keretakan atau perpecahan, maka keakraban tetap terpelihara dan setiap masyarakat akan tetap saling menghargai satu sama lain.

\section{PEMBAHASAN}

Pengobatan tradisional Karo adalah pengobatan yang menggunakan tumbuhtumbuhan yang mengandung khasiat sebagai obat bagi masyarakat. Obat tersebut merupakan obat yang diperoleh langsung dari bahan-bahan alami seperti daun-daunan, biji-bijian, bunga-bunga, buah-buahan serta akar-akar yang dipercaya berkhasiat menyembuhkan penyakit, diolah secara sederhana berdasarkan pengalaman dan penggunaan dalam pengobatan tradisional. Pengetahuan masyarakat Karo terhadap pemakaian tanaman obat berkhasiat sudah ada sejak zaman dahulu dan digunakan sebagai salah satu upaya penanggulangan masalah kesehatan yang dihadapi. Pengetahuan pengobatan ini merupakan warisan budaya Karo yakni berdasarkan pengalaman kejadian-kejadian yang dilihat maupun dialami sekitar tempat tinggal mereka, secara turun-temurun telah diwariskan oleh generasi yang satu dengan generasi berikutnya.

Dalam tingkat kepercayaan masyarakat Desa Kidupen yakni Dinamisme dan Animisme yaitu dilakukan pemujaan dan penyembahan kepada yang dianggap suci dan berkuasa. Dari kepercayaan inilah kehidupan masyarakat mulai dipengaruhi oleh alam gaib. Segala malapetaka atau penyakit yang terjadi pada manusia sering dikaitkan dengan alam gaib atau pengaruh roh-roh halus, oleh karena itu setiap pengobatan penyakit selalu diserahkan kepada seorang guru Mbelin yang dipercayai mengetahui kehidupan dan kejadian-kejadian dalam manusia serta keseimbangan dalam diri manusia dan lingkungannya. 
Persepsi masyarakat Kidupen tentang sehat dan sakit sangat dipengaruhi oleh unsur pengalaman masa lalu, disamping unsur sosial budaya. Persepsi tersebut dibentuk oleh pengalaman, pengetahuan, nilai-nilai dan harapan-harapan, disamping juga pandangan mereka tentang apa yang mereka lakukan dalam kehidupan sehari-hari.

Pengobatan tradisional juga merupakan bagian dari kebudayaan masyarakat Karo di desa Kidupen dalam menciptakan huruf sebagai alat komunikasi yang digunakan untuk menulis mantra-mantra, berbagai jenis obat-obatan untuk menyembuhkan penyakit dan pengalaman-pengalaman kehidupan manusia oleh guru Mbelin. Dengan demikian bahwa pengobatan tradisional Karo merupakan bagian dari kebudayaan yang diwariskan oleh nenek moyang secara turun-temurun yang merupakan hasil karya manusia di Desa Kidupen yakni dalam seni menulis mantramantra di sebuah kulit kayu yang dinamakan "Pustaka Najati"

Tambar (obat) ini dituliskan di dalam kulit kayu atau "lak-lak kayu” disebut "Pustaka”, "Pustaka lak-lak kayu” banyak ragamnya " Pustaka Karo" yang terkenal adalah "Pustaka najati”. Isi "Pustaka Najati” adalah :1) Sungkun berita; 2) Tambartambar; 3) Mangmang; 4) Niktik wari desa siwaluh; 5) Guna wari-wari Karo; 6) Ngenehen nasip ras tuah-rejeki, baban geluh dan lain-lainny (Ginting, 1999:53)

Sistem kepercayaan masyarakat Karo pada zaman dahulu yakni agama Perbegu (Pemena), sehingga kepercayaan tersebut melahirkan 2 jenis pengobatan tradisional yang dikenal yaitu : 1) pengobatan yang diikuti dengan meminta pertolongan roh atau arwah begu orang mati, memakai tabas (mantra) dan memakai atau tanpa memakai ramuan; 2) pengobatan yang memakai pulungen (ramuan) tertentu tanpa tabas-tabas (mantra-mantra), tanpa memanggil roh-roh orang mati dan kuasa-kuasa lainnya hanya menggunakan bahan-bahan khasiat yang telah dikenal dan dipergunakan secara turuntemurun oleh nenek moyang masyarakat Karo.

\section{A. Sejarah Guru Mbelin dalam Pengobatan Tradisional Karo di Desa Kidupen (1970-1990)}


Ilmu, kemampuan dan keahlian seorang guru sehingga dikatakan sebagai guru Mbelin berasal dari berbagai cara, menurut wawancara dengan bapak Tengteng Sembiring, mengatakan bahwa ilmu dan keahlian dari seorang guru Mbelin berasal dari 3 (tiga) cara yaitu:1) Diturunkan oleh Dibata (Tuhan); 2) Diturunkan oleh nenek moyang; 3) Berguru dengan guru ahli.

Keberadaan guru Mbelin di desa Kidupen mulai diketahui sekitar tahun 1930an, ketika melawan penjajah yang datang memasuki Desa Kidupen dengan menggunakan ilmu gaib yang mereka miliki. Guru Mbelin menggunakan ilmunya dengan berbagai cara seperti menggaris jalan (pasar) yang dinamakan Pamaris, membuat angin Topan (angin kaba-kaba) dan lain-lainnya. Peran guru Mbelin pada tahun 1930-1946, masih dalam melawan penjajah yang datang kedesa tersebut.

Setelah pasca kemerdekaan pada tahun 1950-1969 merupakan masa guru Mbelin dan guru-guru lainnya bahkan masyarakat berkeinginan besar untuk memiliki ilmu kuat dan keahlian-keahlian lainnya. Untuk mendapatkan ilmu dan keahlian selain dari talenta yang sudah diberikan Tuhan, maka mereka harus berguru kepada guru yang ahlinya. Pada masa ini dikatakan masa manusia berguru untuk memperoleh ilmu gaib dan keahlian di Desa Kidupen. Ilmu gaib dan keahlian yang dimiliki guru Mbelin dan guru-guru lainnya tersebut digunakan untuk menjaga diri sendiri dari hal-hal buruk dan memperkuat diri dari guru yang lainnya . Sehingga diantara sesama guru sering menguji ilmu gaib yang mereka miliki, bahkan untuk mencari perhatian masyarakat mereka membuat penyakit kepada masyarakat tersebut

Jenis penyakit yang dibuat oleh guru Mbelin pada masa ini yakni jenis penyakit personalistik yang mempengaruhi desa Kidupen dikenal oleh masyarakat luas. Penyakit personalistik dikategorikan sebagai penyakit yang disebabkan oleh agen-agen tertentu yakni karena diganggu roh halus, perlakuan orang lain(tama-tama/aji) dan kengalen(kutukan). Jenis penyakit personalistik yang sering dibuat di desa ini sesungguhnya benar-benar bersifat tradisional antara lain kena si mentas-mentas (kemasukan roh halus), Pengkayah (busung), aji bur-bur (tumor-kanker), aji beot (mulut miring), ndarat dilah (lidah menjulur keluar), siojar-ojari (sakit jiwa karena 
perbuatan orang lain), mereng (sakit jiwa bisa karena perbuatan orang lain dan karena kemasukan roh nenek moyang), birawan (trauma), tidak memiliki keturunan karena birawan, dan tidak memiliki keturunan karena kengalen (kutukan). Penyakit tersebut dibuat karena keinginan guru Mbelin yakni untuk memperlihatkan dan memperkenalkan kemampuannya kepada masyarakat sehingga dirinya banyak dikenal dan permintaan dari masyarakat untuk membuat penyakit karena benci dan iri terhadap orang lain.

Memasuki tahun 1970-an guru Mbelin baru mulai melakukan pengobatan penyakit, baik penyakit personalistik maupun naturalistik dengan praktek pengobatan dilakukan di rumah guru Mbelin maupun mendatangi langsung ke rumah pasien, namun disamping pengobatan dalam membuat penyakit juga masih sering dilakukan. Pengobatan yang dilakukan tersebut banyak menyembuhkan penyakit sehingga menarik perhatian banyak masyarakat. Dalam pengobatan dilakukan dengan memakai ilmu gaib atau mantra-mantra yang merupakan kepercayaan masyarakat terhadap rohroh nenek moyang dan ramuan-ramuan tradisional.

Meningkatnya keinginan masyarakat untuk melakukan pengobatan terhadap guru Mbelin juga dipengaruhi oleh keberadaan puskesmas yang belum ada di Desa Kidupen pada saat itu, maka jika memiliki penyakit masyarakat berobat kepada guru Mbelin, sehingga peran dokter di desa Kidupen pada masa ini hanya terpusat pada guru Mbelin. Banyaknya penyakit yang dapat disembuhkan oleh guru Mbelin, membuat masayarakat diluar desa tersebut mulai berdatangan untuk melakukan pengobatan. Terkenalnya guru Mbelin kepada masyarakat luar bersumber dari interaksi seseorang dengan keluarga, interaksi dengan tetangga dan interaksi pasien atau keluarga pasien dengan pengobatan tradisional. Jika penyakit yang diderita seseorang sembuh, biasanya dalam masyarakat Karo akan saling memberitahukan kepada yang lain (ternina-nina) daerah mereka berobat serta penyakit yang disembuhkan, sehingga semua orang dapat mengetahui keberadaan guru Mbelin di Desa Kidupen.

Bahkan kehadiran agama di Desa Kidupen pada tahun 1980, tidak semertamerta membuat keberadaan guru Mbelin hilang, bahkan pada tahun ini desa Kidupen 
masih sangat digemari masyarakat luar sebagai tempat pengobatan. Mengingat kehidupan masyarakat Karo secara tradisional masih dilakukan, segala kegiatan selalu dihubungkan dengan roh-roh gaib dan upacara ritual serta penyembuhan, sebagian aspek penting dalam kepercayaan tradisional Karo tersebut dalam pelaksanaannya masih terpusat pada guru dan masih sering dilaksanakan.

Kedatangan agama Kristen ke desa Kidupen yang tidak langsung diterima oleh masyarakat karena kepercayaan masyarakat sebelumnya terhadap agama Pemena dan Hindu Dharma masih sangat melekat dan diterima baik oleh masyarakat. Ajaran agama Pemena sangat selaras dengan kehidupan masyarakat Karo yaitu berhubungan dengan arwah-arwah yang sudah mati dan dipercayai dapat melindungi orang yang masih hidup.

Memasuki tahun 1985 merupakan tahun dimana masyarakat Kidupen secara besar-besaran memeluk agama kristen, hal itu ditandai dengan adanya pembaptisan secara massal yang dilakukan oleh gereja GBKP (Gereja Batak Karo Protestan) di desa tersebut dan penginjilan serta penerimaan jemaat oleh agama Katolik hingga pembaptisan. Masyarakat yang ikut memeluk agama Kristen bukan hanya dari masyarakat biasa saja, para guru juga ikut memeluk agama tersebut. Setelah memeluk agama Kristen, masyarakat masih tetap menjalankan kepercayaan mereka secara tradisional, mereka masih melakukan upcara-upacara tradisional, mempercayai adanya makhluk gaib bahkan masyarakat masih memuja mahkluk gaib tersebut, hingga pengobatan penyakit masih pada guru Mbelin. Mereka masih takut jika tidak menjalankan apa yang sudah menjadi tradisi mereka selama ini akan berdampak buruk bagi dirinya dan keluarganya.

\section{B. Eksistensi guru Mbelin dalam pengobatan tradisional Karo di desa Kidupen (1970-1990)}

Eksistensi guru Mbelin di Desa Kidupen memberi pengaruh terhadap masyarakat dan daerah sekitarnya baik positif maupun negative. Hal ini dapat dilihat dari pengaruh guru Mbelin dalam kehidupan manusia seperti pengetahuan tentang 
kejadian-kejadian yang berhubungan dengan manusia, praktek dan kepercayaan tradisional dan perawatan serta penyembuhan berbagai penyakit.

\section{a. Faktor-faktor yang melatarbelakangi guru Mbelin di desa Kidupen banyak dikunjungi (1970-1990)}

Setelah memasuki tahun 1970 guru Mbelin mulai dikenal dalam mengobati berbagai penyakit baik penyakit naturalistik maupun personalistik. Pengetahuan dan pengalaman dalam mengenal dan menyembuhkan berbagai jenis penyakit, ramuanramuan alami untuk pengobatan pengobatan, racikan ramuan-ramuan alami pengobatan dan cara pemakaiannya oleh guru Mbelin, seiring waktu mendatangkan berbagai pasien dengan gejala penyakit yang berbeda-beda dan memunculkan kepercayaan masyarakat baik dalam desa maupun diluar desa dengan keahlian yang dimiliki oleh guru Mbelin sehingga mempengaruhi keinginan berkunjung masyarakat semakin banyak terhadap guru Mbelin di desa Kidupen. Berikut beberapa faktor-faktor yang membuat guru Mbelin banyak dikunjungi di desa Kidupen pada 1970-1990 yakni

1. Keahlian menyembuhkan penyakit Naturalistik dengan bahan rempah-rempah dan mantra-mantra

2. Keahlian menyembuhkan penyakit Personalistik

3. Kepercayaan terhadap penyebab penyakit adalah roh halus

4. Keahlian guru Mbelin dalam menentukan, memilih dan mengolah bahan-bahan ramuan untuk pengobatan tradisional

5. Pemahaman dan pemanfaatan sumber daya alam tumbuhan dalam pengobatan tradisional oleh guru Mbelin

6. Hubungan kekerabatan

7. Hubungan sesama pengguna obat tradisional

8. Tradisi

9. Ekonomis dan Kemudahan dalam mengakses

10. Keterkaitan dan saling ketergantungan

11. Pengobatan realatif murah

12. Kepercayaan terhadap guru yang merupakan sumber pengetahuan kehidupan manusia 
Berkembangnya jenis penyakit-penyakit yang serius juga dipandang sebagai faktor pendorong pemanfaatan pengobatan guru Mbelin. Penyakit-penyakit serius lainnya seperti sakit jantung, kanker, diabetes, darah tinggi dan penyakit-penyakit serius lainnya semakin meningkat karena pola hidup masyarakat yang tidak sehat. Penyakit-penyakit serius tersebut akan mempengaruhi pasien untuk melakukan berbagai tindakan pengobatan untuk memperoleh kesembuhan termasuk dengan mengunjungi pengobatan guru Mbelin dalam mengonsumsi obat-obat tradisional Karo.

\section{b. Faktor-faktor yang mendorong bertahannya guru Mbelin di desa Kidupen}

Pemanfaatan pengobatan tradisional sangat diminati oleh masyarakat Kidupen dan masyarakat diluar desa tersebut, sehingga sangat mendorong bertahannya guru Mbelin sampai sekarang. Dibawah ini ada beberapa faktor-faktor yang mendorong bertahannya guru Mbelin di desa Kidupen yakni :

1. Kemampuan dalam menyembuhkan berbagai penyakit dengan pengobatan tradisional

2. Pengobatan dengan bahan rempah-rempah

3. Keinginan masyarakat untuk mencoba berbagai jenis pengobatan

4. Pemanfaatan sumber daya alam yang ramah lingkungan

5. Dapat digunakan untuk mengobati diri sendiri dan anggota keluarga

6. Adat istiadat yang masih dijalankan

7. Keyakinan dan pandangan hidup

8. Bahan rempah-rempah yang mudah untuk didapatkan

9. Pengobatan yang relatif murah dan mudah

10. Sebagai sumber ekonomi tambahan

\section{c. Jenis-jenis pengobatan penyakit oleh guru Mbelin}

Untuk mengetahui penyakit yang diderita pasien maka tahap-tahap yang dilakukan oleh guru Mbelin yakni memberikan diagnosa kepada pasien seperti bentuk penyakit yang diderita oleh pasien. Kemunculan diagnosa berdasarkan pengalaman 
serta penanganan yang dilakukan guru Mbelin dalam melihat penyakit yang dialami pasien. Dalam mengetahui penyakit muncul dalam diri seseorang, maka guru Mbelin akan memeriksa penyakit yang diderita pasien seperti menggunakan teknik pijat, proses cara perabaan dengan menggunakan alat sebagai media dalam proses pemeriksaan, serta diikuti pertanyaan yang ditujukan kepada pasien tentang gejalagejala yang dialami dan waktu mulai adanya penyakit. Setelah mengetahui penyakit yang diderita pasien, maka guru Mbelin akan menentukan metode pengobatan yang akan dilakukan yakni apakah metode pengobatan dengan menggunakan ramuan, metode berupa tindakan dan gabungan antara keduanya.

Pengobatan dengan ramuan biasanya menggunakan ramuan berupa akarakaran, daun, batang, buah dari tanaman yang dikategorikan sebagai obat. Selain bahan tumbuh-tumbuhan juga menggunakan bahan hewani dan mineral alam lainnya. Pengobatan berupa tindakan seperti alun (mengurut), kicik/raleng tendi (memanggil jiwa), tabas (Mantera), semburi (sembur), erminak (memakai minyak), erdampel (menempelkan ramuan), anggih (tetes), erpangir (berlangir), erkuning (memakai kuning), oukup (mandi uap beramuan), dan surungi(mengolesi ramuan yang dihaluskan). Sedangkan pengobatan gabungan yaitu dengan melakukan pengobatan tindakan dan memakan/meminum ramuan.

Untuk mendapatkan ramuan-ramuan pengobatan penyakit baik guru Mbelin dan masyarakat dapat mencarinya di hutan, karena ketersediaan bahan-bahan baku masih mudah diperoleh di hutan yang dekat dengan pemukiman penduduk, hal ini juga ikut mempengaruhi peminatan terhadap obat-obat tradisinal Karo. Antipasi kekosongan bahan baku dilakukan dengan cara penyediaan bahan baku dalam jumlah yang besar. Bahan baku besar kemudiaan dikeringkan atau kemudian dihaluskan agar lebih tahan lama. Namun jika bahan ramuan-ramuan pengobatan yang diperlukan tidak ditemukan dihutan, maka dapat membelinya ditempat yang biasa menjual ramuanramuan tradisional Karo.

Berdasarkan wawancara yang dilakukan dengan beberapa narasumber, maka jenis penyakit yang dapat disembuhkan oleh guru Mbelin yaitu : 
Penyakit personalistik antara lain: kena si mentas-mentas (kemasukan roh halus), aji bur-bur (tumor-kanker), aji beot (mulut miring), ndarat dilah (lidah menjulur keluar), siojar-ojari (sakit jiwa karena perbuatan orang lain), mereng (sakit jiwa bisa karena perbuatan orang lain dan karena kemasukan roh nenek moyang), birawan (trauma), tidak memiliki keturunan karena birawan, dan tidak memiliki keturunan karena kengalen (kutukan).

Penyakit naturalistik antara lain: Ginjalen (penyakit ginjal, Batu karang/karangen (batu karang), mah (maag), Bel-bellen/ndabuh tampuk tuka (ambeien), Titanusen (infeksi tetanus), Salah urat (Urat bermasallah), Terselimpek (sendi bergeser), Selek (Tulang bergeser),tersiher (capek badan), masuk angin, lelaki kurang gairah, nusur tuka (turun usus), Lapermupus (susah memiliki keturunan), Cekak-cekak (makanan yang nyangkut di tenggorokan), melawensa tubuh (anak yang terlambat lahir), ugahen (kudis), Katarak, Luka Bakar, Tagut Nipe (Digigit ular dan penyakit berbiasa lainnya), Luka karena benda tajam, Luka karena disengat serangga, soler (mecret), Panas dalam, Batu Empedu, Tipus, Sakit Kuning, Sakit gigi, Sakit gula (Diabetes), Sesak nafas, Mandelen (amandel), Rancangen (angin duduk), Sakit pasar (penyakit kelamin), Batuk, Pilek, Penyakit asma, Rematik, Bisul, Alergi, Panas dalam dan lain-lainnya.

\section{d. Peramuan pengobatan dengan bahan rempah-rempah}

Pengobatan tradisional ini dapat dilakukan dengan bahan-bahan rempah saja, gabungan bahan rempah-rempah dengan mantra-mantra, dan hanya menggunakan mantra-mantra. Berdasarkan metodenya, pengobatan tradisional dapat dikategorikan kedalam beberapa metode pengobatan yakni pengobatan dengan menggunakan ramuan yang dimakan dan diminum, metode tindakan murni yakni mengurut dan menyembur, dan metode kombinasi ramuan dan tindakan yakni mengurut dan menyembur.

Pengobatan dengan ramuan biasanya menggunakan ramuan berupa akarakaran, daun, batang, buah dari tanaman yang dikategorikan sebagai obat oleh 
masyarakat. Selain bahan tumbuh-tumbuhan juga menggunakan bahan hewani dan mineral alam lainnya. Pengobatan berupa tindakan seperti mengurut(alun), memanggil jiwa (kicik/raleng tendi), mantera (tabas-doa), sembur (semburi), memakai minyak (erminak), menempelkan ramuan (erdampel), anggih (tetes), erpangir (berlangir), erkuning (memakai kuning), oukup (mandi uap beramuan), dan surungi (mengolesi ramuan yang dihaluskan). Sedangkan pola pengobatan gabungan yaitu dengan melakukan pengobatan tindakan dan memakan/meminum ramuan.

\section{e.Peramuan pengobatan penyakit dengan tabas-tabas (mantra-mantra)}

Sedangkan penyakit yang hanya menggunakan tabas-tabas (mantra-mantra) yakni penyakit yang disebabkan oleh makhluk halus. Penyakit ini hanya bisa disembuhkan dengan mantra-mantra yang digunakan oleh guru Mbelin. Menurut para guru Mbelin, ketika pasien datang untuk mengobati penyakit karena makhluk halus dapat dikenali langsung. Hal tersebut dikarenakan guru Mbelin mampu merepat (menerawang) serta dapat melihat dan berkomunikasi dengan makhluk halus. Namun proses nungkun-nungkuni (bertanya) tetap dilakukan oleh guru Mbelin, dalam proses ini guru Mbelin akan menerawang dan memberitahu penyebab pasien diganggu makhluk halus, waktu dan tempat pasien diganggu makhluk halus, serta siapa orang yang terlibat dalam membuat penyakit tersebut. Dalam proses nungkun-nungkuni (bertanya) ini, guru Mbelin biasanya ada yang merokok, ada juga yang melihat ke dalam air dalam mangkok yang sudah diberi mantra. Pada saat inilah guru tersebut berkomunikasi dengan makhluk halus.

Setelah diketahui penyakitnya maka guru Mbelin akan melepaskan mahkluk halus tersebut dari pasien dengan mantra-mantra. Kemudian setelah pelepasan maka dibuatlah pangir untuk pasien agar dapat membersihkan diri dari makhluk halus, menghindari akan diganggu lagi oleh makhluk halus serta menyembuhkan penyakitpenyakit lainnya. Bahan-bahan yang digunakan untuk Erpangir yaitu Jeruk purut, baja (getah kayu besi), minyak kelapa, dan air dalam mangkok putih. Guru Mbelin akan meramu erpangir tersebut dengan cara jeruk purut dipotong menjadi beberapa bagian 
dan dicampur dengan air dalam mangkok putih, minyak kelapa dan baja. Setelah itu guru Mbelin kembali memberikan mantra-mantra dan diberikan kepada pasien untuk dipangirkan.

Untuk melakukan pengobatan, masyarakat akan datang langsung ke rumah guru Mbelin atau membuat janji terlebih dahulu. Ketika bertemu dengan pasien saja guru Mbelin dapat mengetahui penyakit yang diderita oleh pasien, seperti penyakit yang disebabkan oleh makhluk halus atau karena penyakit ketidakseimbangan tubuhnya saja. Namun untuk mengetahui lebih dalam mengenai gejala dan penyakit yang dialami pasien, maka akan dilakukan nungkun-nungkuni (bertanya ). Pada proses nungkun-nugkuni (bertanya) ini biasanya akan terjadi bertutur (saling mengenal berdasarkan adat Karo), sehingga dapat terjalin persaudaraan diantara pasien dan guru Mbelin.

\section{f. Peramuan pengobatan penyakit dengan bahan rempah-rempah dan tabas-tabas (mantra-mantra)}

Umumnya penyakit yang memakai bahan rempah-rempah dan mantra-mantra yakni penyakit mulajadi (untuk laki-laki) dan sakit muda (untuk perempuan). Jenis penyakit tersebut yakni : Untuk penyakit mulajadi (pada laki-laki) yaitu : penyakit karang, sipilis, impoten, ejakulasi dini, sedangkan untuk penyakit sakit muda (pada perempuan) yaitu penyakit la mupus (susah memiliki keturuanan), la erlau сиси (payu dara yang tidak menghasilkan ASI), memperlancar melahirkan, gondok, keputihan, haid, keguguran.

Gejala penyakit mulajadi dan sakit muda adalah telapak tangan sering berkeringat, tidak tahan jongkok yang lama, jika baru bangun dan langsung berdiri penglihatan menjadi berkunang-kunang, selera maka berkurang, dan gampang masuk angin. Untuk pengobatan penyakit tersebut harus dilengkapi dengan tawar (jamu), minuman, kuning-kuning, sembur-sembur, dan peridin (bahan-bahan untuk mandi). Pengobatan penyakit mulajadi dan sakit muda harus dilihat dan diperiksa langsung oleh

guru Mbelin, untuk penyembuhannya bahkan dapat memakan waktu yang lama, serta 
kerajinan dalam memkai pengobatan yang diberikan oleh guru Mbelin tersebut. Dalam pengobatan tersebut juga melakukan berbagai ritual-ritual, disamping dengan pengobatan rempah-rempah.

\section{g. Faktor-faktor yang mempengaruhi berkurangnya penggunaan pengobatan} tradisional Karo oleh guru Mbelin di desa Kidupen setelah tahun 1990

a.Internal

1.Kedatangan dan perkembangan gereja

2.Kepercayaan akan adanya Tuhan

3. Guru Mbelin banyak menyembunyikan identitas dirinya

4. Pembakaran mantra-mantra dan alat-alat dalam pemujaan

5. Kesedian rempah-rempah pengobatan tradisional yang mulai sulit didapatkan

6. Berkurangnya yang ahli dalam pengobatan tradisional

b.Eksternal

1.Perkembangan zaman semakin modern

2.Pendidikan

3.Pengaruh dari teknologi modern

4.Fasilitas kesehatan yang sudah mulai ada di daerah pedesaan

5.Masyarakat lebih menyukai hal-hal yang praktis dan mudah

6. Kurangnya peranan media massa

\section{h. Kearifan lokal pengobatan tradisional Karo di desa Kidupen}

Kearifan lokal pengobatan tradisional oleh guru mbelin di desa Kidupen yakni : 1) Pengobatan dengan menggunakan tabas (mantra); 2) Pengobatan dengan menggunakan ramuan-ramuan tradisional; 3) Jenis obat minyak alun (urut); 4) Kuning (Param); 5) Sembur; 6) Tawar; 7) Dampel; 8) Surung-surung; 9) Erpangir Kulau

Semua pengobatan tersebut merupakan warisan nenek moyang yang sudah dilakukan secara turun-menurun dan sering dikonsumsi oleh masyarakat Karo, bahkan sampai sekarang. Bahan-bahan yang diperlukan juga diperoleh dari alam, serta 
pembuatan dan pengaplikasian yang mudah untuk dilakukan bahkan bisa dibuat oleh masyarakat. Pengalaman dari para masyarakat yang berobat, banyak yang mendapat kesembuhan dalam penyakit baik itu penyakit personalistik dan naturalistik. Khasiat pengobatan dari ramuan-ramuan alami serta mantra-mantra yang digunakan tersebut mampu menyembuhkan penyakit.

Berdasarkan hasil penelitian yang dijelaskan diatas maka dapat dikatakan pengobatan yang dilakukan guru Mbelin pada tahun (1970-1990) adalah bereksistensi dilihat dari kepercayaan masyarakat Karo terhadap pengobatan tradisional oleh guru Mbelin dibandingkan dengan pengobatan medis. Sistem pengobatan yang digunakan berasal dari kebudayaan turun-menurun dari nenek moyang yang sudah dilakukan dari sejak dulu yang merupakan khas suku Karo sehingga membuat masyarakat memiliki alternatif pengobatan dengan pengobatan tradisional oleh guru Mbelin.

\section{PENUTUP}

Sejarah pengobatan tradisional oleh guru Mbelin di Desa Kidupen yaitu mengalami perkembangan mulai dari tahun 1970-1990. Guru Mbelin yang sebelumnya dikenal suka membuat penyakit, namun mengalami perubahan dan perkembangan pada tahun 1970-1990 yakni membuat pengobatan tradisional dengan menggunakan rempah-rempah, mantra-mantra dan gabungan rempah-rempah dan mantra-mantra.

Faktor-faktor yang melatarbelakangi guru Mbelin banyak dikunjungi pada tahun 1970-1990 yakni keahlian menyembuhkan penyakit naturalistik dengan bahan rempah-rempah dan mantra-mantra, keahlian menyembuhakan penyakit personalistik, keahlian guru Mbelin dalam menentukan, memilih dan mengolah bahan-bahan ramuan untuk pengobatan tradisional, kepercayaan terhadap penyebab penyakit adalah makhluk halus, pemahaman dan pemanfaatan sumber daya alam tumbuhan dalam pengobatan tradisional oleh guru Mbelin, hubungan kekerabatan dan kemudahan dalam mengakses daerah.

Faktor-faktor yang mempengaruhi bertahannya guru Mbelin di desa Kidupen

yakni kemampuan dalam menyembuhkan berbagai penyakit dengan pengobatan 
tradisional seperti dengan rempah-rempah dan mantra-mantra, keinginan masyarakat untuk mencoba berbagai jenis pengobatan, pemanfaatan sumber daya alam yang ramah lingkungan , untuk mengobati diri sendiri dan anggota keluarga , adat istiadat yang masih dijalankan, keyakinan dan pandangan hidup, bahan rempah-rempah yang mudah untuk didapatkan, pengobatan yang relatif murah dan mudah, sebagai sumber ekonomi tambahan

Peramuan rempah-rempah dalam pengobatan tradisional Karo berasal dari bahan-bahan rempah-rempah dari alam diolah secara tradisional, turun-temurun, berdasarkan resep nenek moyang, adat istiadat, kepercayaan atau kebiasaan, baik bersifat magic maupun pengetahuan tradisional. Pengobatan tradisional ini dapat dilakukan dengan bahan-bahan rempah saja, gabungan bahan rempah-rempah dengan mantra-mantra, dan hanya menggunakan mantra-mantra. Metode pengobatan yakni pengobatan dengan menggunakan ramuan yang dimakan dan diminum, metode tindakan murni yakni mengurut dan menyembur, dan metode kombinasi ramuan dan tindakan yakni mengurut dan menyembur.

Pengobatan tradisional oleh guru Mbelin di desa Kidupen dapat disimpulkan bereksistensi pada tahun 1970-1990, hal ini ditandai dengan pengobatan yang dilakukan guru Mbelin tersebut dikenal luas oleh masyarakat Karo dan dipercayai sebagai alternatif pengobatan yang dapat menyembuhkan berbagai penyakit baik personalistik maupun naturalistik dengan metode pengobatan dengan rempah-rempah maupun mantra-mantra (tabas-tabas). 


\section{DAFTAR REFERENSI}

Bangun, Tridah. 1986. Manusia Batak Karo. Jakarta : PT Inti Idayu Press

Daliman. 2012. Metode Penelitian Sejarah. Yogyakarta: Ombak

Foster dan Anderson. 1986. Antropologi Kesehatan. Jakarta : Universitas Indonesia ( UI-Press)

Ginting, Leo Joosten dan Ginting, Kriswanto. 2014. Tanah Karo (Selayang Pandang. Medan : Bina Media Perintis

Gintings, E.P. 1999. Religi Karo. Kabanjahe : GBKP Abdi Karya

Humaedi, Alie. 2016. Etnografi Pengobatan : Praktik Budaya Peramuan dan Sugesti Komunitas Adat Tau Taa Vana. Yogyakarta : LKiS

Koentjaraningrat. 1998. Pengantar Antropologi II. Jakarta : PT Rineka Cipta

Nazir.Moh. 2003. Metode Penelitian. Jakarta: Ghalia Indonesia

Noorkasiani. 2009. Sosiologi Keperawatan.Jakarta : EGC

Purba, Edward dan Yusnadi. 2016. Filsafat Pendidikan. Medan : Unimed Press

Pranoto, Suhartono W. 2010. Teori dan Metodologi Sejarah. Medan : Graha Ilmu

Rochmat, Saefur. 2009. Ilmu Sejarah dalam Perspektif Ilmu Sosial. Yogyakarta: Graha Ilmu

Sulasman. 2014. Metodologi Penelitian Sejarah (Teori, Metode, Contoh Aplikasi). Bandung: CV Pustaka Setia

Tarigan, Sarjani. 2011. Kepercayaan Orang Karo (Tempo Doeloe). Medan : BABKI (Balai Adat Budaya Karo)

Tarigan, Sarjani. 2017. Pengobatan Tradisional Karo. Medan : BABKI (Balai Adat Budaya Karo) 